\title{
Expanding the Scope of Corporate Social Responsibility (CSR): Strategizing Skill Development in the Indian Scenario
}

\author{
Anupama Sadasivan ${ }^{*}$
}

\section{Abstract}

India is transitioning demographically with a large population of youngsters. To harness this population trend into a 'demographic dividend,' it is essential to enhance the skill level of our youth. The Government of India (GoI) has taken many proactive measures in this regard. 'Skill India Campaign' is one such measure. Though India's corporate sector has also been contributing to skill training through its Corporate Social Responsibility (CSR) initiative, the efforts have been few and far between. The first part of this paper explores the Skill scenario of India, and the role played by both Public and Private sector to address the current skill gap. The second part of the paper suggests a possible solution to address the 'skill gap' through a proactive Public-private partnership (PPP) by implementing a remodelled CSR strategy. Government and corporate sector can work together in the skill training arena through CSR and make it a mutually beneficial, sustainable activity to develop India into a "skill capital" of the World. The potential advantages of such a partnership for each player involved are also explored in detail in this part.

Keywords: Skill India campaign, sustainable CSR, Employee volunteering programs, Public-private partnership

*University of Kerala, Thiruvananthapuram, India; sadasivan.anupama@gmail.com 


\section{Introduction}

India has the world's largest youth population with 365 million 1024 year-olds as per the latest UN report. The 2011 census data reveal that 62.5 percent of total Indian population belongs to the economically active category. India's labor force is expected to register a remarkable increase of $25 \%$ by 2025 while other industrialised countries face a decline in the labour force by $4 \%$ or more. The average age of Indian population by 2020 is expected to be 29, as against developed nations such as U.S.A (40 years), Europe (46 years) and Japan (47 years) (Krishnan et al., 2017). This ageing of the population is expected to create a shortage in the skilled workforce (56.7 million internationally) by 2040. This will lead to an increase in demand for young and skilled labour force which can be advantageous for India, possibly making the country a 'skill capital' (Pai, 2017). India's large workforce, if harnessed properly will offer the country an opportunity for rapid economic growth with stability (UNFPA, 2014). It is crucial to enhance their skill level and sometimes even re-skill or up-skill the young demography from the current skill level. "Skill" in the context is defined as the ability or the expertise to do a task well, to reap the full benefit of this demographic trend, Skills can more specifically be categorised into life skills, labour skills, social skills, soft skills, and hard skills.

Life skills, as the name suggests equips, an individual to deal with life efficiently. Individuals' wellbeing and ability to thrive depend on his life skills. Social norms and community expectations heavily influence life skills and hence it is an elastic concept but even so decision making, problem solving, assertiveness, mindfulness, empathy and resilience are considered some universally essential life skills to thrive in society. Labour skills are labour or profession specific skills essential to do a job well, like the skills required by an electrician or plumber. Social skills are those skills that help establish the social wellbeing of a person and ensure a good social life by improving the quality of the interpersonal interactions. Soft skills are again similar to social skills and are an umbrella term used to include skills such as interpersonal skills, communication skills, people skills, social and emotional intelligence and the like. Hard skills are task-specific or situation-specific skills and help an 
individual to do a job well. The term 'skilling' is also important in this context. 'Skilling' in simple terms refers to the process by which 'the skills' are taught. This process of teaching new skills to people also involves re-skilling and up-skilling from existing skill level to equip people with the essential life and employability skills to improve as well as enhance their quality of life, for a better future. In the context of this paper 'skill' and 'skilling' is not limited to the unemployed younger generation but the 'employees' of the corporate sector. It is further discussed below how Corporate Social Responsibility (CSR) can provide the nurturing environment of 'give and take' for employees and local community learn and teach essential skills to and from each other and benefit from the process. Eventually, only such a nurturing environment of give-and-take can sustain itself in the future and set the path for a sustainable CSR

While India's national literacy average is 74.2 percent, only about 2.5 percent population has any vocational education/skill (Sing, 2017). It is high time to address this lapse and equip the young population with essential skills to improve their wellbeing and overall quality of life. A possible solution for this scenario is to develop synergy among vocational institutions (government), corporate sector and youth. India's current training capacity through its Industrial Training Institutes (ITIs) is estimated to be only 25 lakhs per annum, while double this number (50 lakh) of young people enters the workforce every year (Krishnan et al., 2017). Thus growing young population is outpacing country's economic growth and institutional training capacity. A sudden increase in training capacity of ITI is unrealistic and unsustainable. While a slight perspective change can address this issue by bringing in an already existing player that is the corporate sector with its Corporate Social Responsibility (CSR) into the skill training arena. "Skilling India" or the process of equipping young India with essential skills is a huge task and government cannot accomplish this alone. The right approach in policy, investment and youth engagement is essential for harnessing this narrow window of demographic dividend for country's progress. The Government of India (GoI) established 'Ministry of Skill Development and Entrepreneurship (MSDE) with the aim to accomplish such challenges of skilling young India. 


\section{Government's Role in Skilling India}

Skilling workforce is important to ensure country's progress and development. Present employment scenario makes it impossible to sustain or survive without skills. The GoI has taken many proactive measures to ensure country's skill development, for instance, to unify and bring coherence to a highly fragmented skill ecosystem the Ministry of Skill Development and Entrepreneurship (MSDE) was established. This Ministry is primarily tasked with ensuring coordination, coherence and role clarity within India's vocational and skill training scenario. Skill India Mission was the first campaign launched by MSDE with the aim of training 40 crore Indian in different skills by 2020. National skill development mission, National policy on skill development and entrepreneurship, Pradhan Mantri Kaushal Vikas Yojana (PMKVY), Deen Dayal Upadhyay Grameen Kaushal Yojna (DDUGKY), Pradhan Mantri MUDRA Yojana are some of the schemes included in this campaign. Broadly all these schemes aim to ensure skill training, capital funds, connectivity and jobs to Indian youth.

National Skill development mission aims to coordinate and consolidates various skilling efforts and expedite cross-sector decision-making process. National policy on skill development and entrepreneurship aims at countries overall human resource development through "Sabka Saath, Sabka Vikas" (Collective Efforts for Inclusive Growth). PMKVY is a skill certification scheme aimed at providing industry relevant skill training empowering youth to secure better livelihood. Under this scheme, training and assessment fees are borne completely by the government. The scheme also assesses and certifies prior learning experience or skills under Recognition of Prior Learning (RPL). DDU-GKY is a placement-linked skill training program aimed at making rural youth economically independent by empowering them with skills and placing them in jobs. PMKVY intends to impart skills to one crore youth by 2020. Pradhan Mantri MUDRA Yojana was launched with the aim of transforming Indian youth from job seekers to job creators by providing funding to noncorporate small business sectors through MUDRA (Micro Units Development and Refinance Agency). 
National Skill Development Policy reports that India currently suffers from the dual contradiction which is an insufficient supply of highly trained workforce on the one hand and the nonemployability of large sections of educated but unskilled youth, on the other (National Skill Development Policy, 2015). Almost 90\% of jobs in India demand vocational skills, but only $7 \%$ of youth in the 15 to 29 age group receive any (formal/informal) vocational training (Rajan, 2016). The training capacity of Industrial Training Institutes (ITIs) and Industrial Training Centres (ITCs) which form the backbone of its vocational training ecosystem is limited to 25 lakhs per annum (Krishnan et al., 2017). "Skill India campaign" aimed at training 40 crore Indians by 2020 requires annual spending of Rs 19,000 crore in vocational training alone every year, up to 2020 (Raman, 2016). Lack of adequate training infrastructure, skilled trainers and funds may thus force the government to fall short of its skill training target.

\section{Corporate Sector's role in Skilling India}

Corporate sector cannot function in isolation. It is dependent on the society, in which it functions, for the resources with which to function- resources such as raw materials, human resource, technology, the capital. Hence it is expected to adhere to a code of conduct, to function productively and responsibly. At the same time, it is expected to give something back to the society through socially responsible activities or Corporate Social Responsibility (CSR) because of the sector 'profits' from the 'resources' drawn from society. CSR is essentially rooted in an ideology of 'give and take'. Since the corporate sector is drawing resources from the society and profiting from such activities, it is expected to give something back to the society. Corporate can contribute to sustainable economic development through a well-designed CSR strategy by involving its employees, the local community and society at large, and improve the overall quality of life of all parties involved (The World Business Council for Sustainable Development, 2000).

The concept of CSR framework for skill development is not new to India; some of its corporate giants such as Dr Reddy Laboratories, Axis Bank, Bosch India, Tata, Wipro, and Reliance already pursue 
extensive and voluntary CSR strategy for skill training throughout the country. 'Livelihood Advancement Business School' of Dr Reddy's Foundation has been successfully training 18-35 year-olds in business skills and soft skills in over 75 centres in 19 states across India. 'Sustainable Livelihood Program' run by Axis Bank has been providing remedial education, vocational education and rural entrepreneurship to over one million people pan-India since 2017. Bosch India foundation has also been carrying out vocational training for school children, school dropouts, local artisans, and local community on both short-term and long-term basis. Tata's Strive is one of the first group CSR program aimed at youth skill development and addresses the upcoming demography-skill gap and need for specific skill training initiatives aimed at financially weaker sections and the need to acclimatise the unskilled and under skilled youth to the challenging work environment. Wipro's 'Mission $10 x$ ' is a CSR initiative working towards improving the employability of engineering graduates from faculty training across colleges in India. Reliance has also been undertaking various vocational training programs among local youth and employing them in their project areas as part of their CSR initiatives.

At present, government policy has forced a shift from voluntary CSR to mandatory CSR initiatives. As per section 135 of Company law, corporate should set apart at least $2 \%$ of their profit for CSR activities. This law applies to those companies with net worth of 5 billion rupees or a turnover of 10 billion rupees or a net profit that exceeds 50 million rupees. About 8,000 Indian companies meet this definition, which would equate to $12,000-15,000$ crore rupees annually, as per the Economic Times statistic (Economic Times, 2012). Such statistic indicates that a present shift in focus on the CSR front towards skill development sector can not only help India attain its skill development targets but prove to be a source of fruitful public-private partnership. Such a CSR strategy will help expands corporate sector's focus from social welfare to skill development. The shift from voluntary to mandatory CSR has forced many new corporate players into the CSR scenario through company law. While on the one hand, many corporate players are on the lookout for innovative ways to design their CSR strategy and utilise their CSR funds, others are viewing CSR as an essential evil to be dealt with through passive donations. This is where the 
government can take a proactive role to promote the corporate involvement in 'Skill India' campaign. This model has already been tested to some extent when government promoted corporate involvement in 'Swaach Bharat Mission'. Corporates were given the opportunity to either contribute financially to the mission or take up direct work of sanitation in selected villages/ blocks/ districts, in partnership with local government (Ministry of Drinking Water and Sanitation, Govt. of India, 2017).

But corporate involvement in "Skill India" mission is perhaps more relevant and comes within the purview of many organizations in contrast to the concept and mission of sanitation. Skills or abilities are what differentiates one organisation from another. Skills are the basic foundation or the smallest atom of an organisation. Skills are the basis on which an organisation selects, differentiate, and promote its employees. Skills are the essential factor that the organisation invests in the name of training and development. Skills/abilities or competencies are, in short, a matter of essential concern for every organisation. Each organisation has some of its own specific skill sets, and some skill sets are relevant universally. Hence, by involving corporate sector in the "Skill India" campaign either by inspiring them to contribute financially or by prompting them to take up direct work of skill promotion in selected villages/blocks/districts, in partnership with local skill training centres, the government is essentially inviting some of the best 'skill training experts' available in the country to contribute productively to the skill deficient arena.

The government has been striving hard to address the 'skill gap' in society but falling short of its target due to infrastructural, expert and capital limitations. The corporate sector has also been making its contribution to the skill training scenario, but the efforts are not coordinated or unified as is required to address India's current situation. In the next session, efforts have been made to address a possible solution to this issue by suggesting a public-private partnership (PPP) in skill training sector. Table 1 explores the advantages of promoting such a PPP in the skill training sector. Efforts have been made to trace the possible advantages from previous studies. At a glimpse, such a PPP looks promising not just for the government and the corporate sector establishments 
involved but also for individuals involved- both at the employee level as well as the local unskilled and under skilled youth level. In the long run, only such a framework, which supports the individual as well as the system, can lay the foundation for a sustainable CSR strategy.

Table1 Exploring the possible Advantages of Public-Private Partnership through CSR in the skill development sector

\begin{tabular}{|c|c|c|c|}
\hline Government & $\begin{array}{c}\text { Corporate/ } \\
\text { Organizations }\end{array}$ & Employees & $\begin{array}{c}\text { Local } \\
\text { Community }\end{array}$ \\
\hline $\begin{array}{l}\text { Improve the } \\
\text { skill training } \\
\text { scenario by } \\
\text { channelling } \\
\text { existing } \\
\text { corporate } \\
\text { infrastructure } \\
\text { through CSR. }\end{array}$ & $\begin{array}{l}\text { Fulfil the need to } \\
\text { engage in legally } \\
\text { mandated CSR. } \\
\text { Ensurea supply of } \\
\text { locally skilled } \\
\text { workforce through } \\
\text { training. }\end{array}$ & $\begin{array}{l}\text { Opportunity to } \\
\text { engage with the } \\
\text { local } \\
\text { community. } \\
\text { Make a } \\
\text { meaningful } \\
\text { contribution to } \\
\text { society. }\end{array}$ & $\begin{array}{l}\text { Easy /local access } \\
\text { to skill learning/ } \\
\text { re-skilling/ } \\
\text { up-skilling } \\
\text { opportunities } \\
\text { provided by top } \\
\text { corporate }\end{array}$ \\
\hline $\begin{array}{l}\text { No additional } \\
\text { investment in } \\
\text { social or } \\
\text { economic } \\
\text { capital } \\
\text { required for } \\
\text { training } \\
\text { young India }\end{array}$ & $\begin{array}{l}\text { Attract best } \\
\text { employees and } \\
\text { retain them } \\
\text { Promote skill level } \\
\text { of employees } \\
\text { Improve } \\
\text { employee- } \\
\text { organisational } \\
\text { relationship. }\end{array}$ & $\begin{array}{l}\text { Developing } \\
\text { essential } \\
\text { competencies } \\
\text { through real-life } \\
\text { social exposure. }\end{array}$ & $\begin{array}{l}\text { Accessibility toa } \\
\text { competent } \\
\text { professional who } \\
\text { is employed by } \\
\text { top corporate }\end{array}$ \\
\hline $\begin{array}{l}\text { Promote an } \\
\text { essential and } \\
\text { sustainable } \\
\text { framework } \\
\text { for legally } \\
\text { mandated } \\
\text { CSR }\end{array}$ & $\begin{array}{l}\text { Promote growth } \\
\text { need of the } \\
\text { employees by } \\
\text { providing them } \\
\text { opportunities to } \\
\text { contribute } \\
\text { productively to } \\
\text { society }\end{array}$ & $\begin{array}{l}\text { Improve Self- } \\
\text { worth through } \\
\text { meaningful } \\
\text { contributions. }\end{array}$ & $\begin{array}{l}\text { Better } \\
\text { apprenticeship, } \\
\text { internship } \\
\text { opportunities }\end{array}$ \\
\hline $\begin{array}{l}\text { Channel 'skill } \\
\text { experts' from } \\
\text { the corporate } \\
\text { field to train } \\
\text { the younger } \\
\text { generation }\end{array}$ & $\begin{array}{l}\text { Promoting the } \\
\text { public image of the } \\
\text { corporate sector } \\
\text { Identifying new } \\
\text { markets. }\end{array}$ & $\begin{array}{l}\text { Improved job } \\
\text { engagement, } \\
\text { and job } \\
\text { satisfaction. }\end{array}$ & $\begin{array}{l}\text { Improved quality } \\
\text { of life due to } \\
\text { better and easily } \\
\text { available skill } \\
\text { learning } \\
\text { opportunities. }\end{array}$ \\
\hline
\end{tabular}




\section{Advantages to the Government Sector for partnering with Corporate for Skilling India}

Systemic infrastructural and capital limitations in providing skill training to youngsters can affect India's progress and stability in the long run. Particularly when the growing young population is left to their own devices rather than targeted for skill development, the "demographic dividend" will be wasted without the required skills and jobs. The youngsters could also become a source of future trouble and possible unrest if not gainfully occupied. Hence it is essential for a country like India to train its future demographic and turn it into a potential asset. This is where the government can make a difference by actively involving the corporate sector through Corporate Social Responsibility (CSR) initiatives for skilling Indian youth. "Skilling" in this context is defined as the process of equipping an individual with the essential life and labour skills. By encouraging active involvement and investment in youth skill training and development through programmes such as the Skill India campaign, the government will be providing a sustainable framework for CSR spending, while ensuring campaign success to skill 40 crore Indians. By channelising corporate skills and funds for this aim, essential and scare resources like time, money, human resource and technical skill sets, often in short supply in the governmental ITIs and ITCs set-ups can be channelised through the corporate sector, to promote vocational training and skill development of young India. The government will be ensuring the involvement of some of the most expert resource persons in the country in the skill training sector through industrial participation and partnerships. Collaborations with the industrial sector can benefit the local community and youth through apprenticeship programs, short certifications, student internship opportunities and job placements. Thus the government can help the corporate sector to effectively contribute to the country's overall development through CSR initiatives. The government can play the role of an active mediator between the local community and corporate sector to promote skill training through sustainable CSR strategies. 


\section{Advantages to the Corporate on Partnering with the Government}

Corporate involvements in skilling India is expected to prove advantageous not just to the government, the local community or the society at large but also to the corporate sector in multiple ways. Firstly, if a corporate sector involves in skill training of local community as its CSR strategy, it provides an avenue for optimal utilisation of CSR funds. Secondly, it provides 'real-life training scenarios' for skilling (promoting skills among) corporate employees through Employee Volunteering Programs (EVPs) designed through such CSR framework. Thirdly, by promoting and enhancing the skill level of local community, corporate can ensure skilled and competent labour supply for its future needs, and fourthly it promotes close interaction with the local community, thereby promoting the public image of the company and opens upon avenues for exploring future markets. Skill learning scenarios are created in the local community and among the employees. An ideal environment for sustainable CSR is one of 'give and take' where knowledge sharing between the local community and the organisations' employee volunteers, is made possible.

Companies make huge investments in selection, training and development of its employees. After selection companies train the selected employee to ensure appropriate 'employee job fit'. Such training programs are often designed to build and upgrade the skill level of employees. Additionally, such programs give employees the feeling that their organisation cares about them, promoting a sense of organisational identification, which helps reduce attrition rates (erosion of workforce to a competitor). Instead, if employees are given an opportunity to involve in the CSR activities designed to promote social welfare they are directly involved in promoting tangible social welfare in the local community. They can directly perceive the benefit of involving in such welfare activities, when they see the result of their involvement, resulting in progress and welfare of the local community.

By designing a CSR framework that promotes employee involvement through EVPs, companies can have a dual advantage, that is, in addition to satisfying their legal obligation for CSR, they 
are also providing their employee 'training opportunities' to cater to their growth needs and improve their skills through mentoring and teaching youngsters. EVPs or Employee Volunteering programs can be simply defined as a planned and managed leadership effort by the employer to motivate and enable employees to serve community needs effectively (Anaheim, 2013). Involving in community skills training programs through EVPs provides employees exposure to real-life social situations, promoting an active learning environment for skill up-gradation. This is why organisations should actively promote EVPs as part of their CSR strategy. Strong CSR practices can help in attracting, recruiting and retaining the best talents as shown in multiple studies (Khanna and Gupta, 2011). Jones (2010) found that employees' attitudes about CSR program were positively associated with organisational pride and identification, which in turn predicted employees' intentions to remain with the organisation, organisational citizenship behaviour, and in-role performance. Collective involvement in designing and carrying out CSR activities has also been found to promote a sense of belongingness among the employees (Bauman et al., 2012).

\section{Advantages to the Employee Involving in Employee Volunteering Programs (EVPs)}

Simply stated, there is a limit to the extent of satisfaction one's work, or job can provide. In their quest for happiness, human beings keep looking for more. This is where Employee Volunteering Programs or EVPs can help. EVPs are programs that motivate employees to serve their community effectively. As Coert Visser points out, "'good work' is about enjoying doing ones best (at work) while contributing to something beyond oneself'. Helping others, relating to others, mentoring and teaching, provides means through which growth needs can be attained. These are precisely the kind of opportunities that Employee Volunteering Programs (EVPs) provides. Studies indicate that employees can derive a sense of purpose and significance from work they perceive as something that contributes to individuals' well-being, improves their community, or is vital to society (Grant, 2007; Pratt and Ashforth, 2003; Wrzesniewski, 2003). 
For instance, it could be the success of a smart classroom established by the organisation with the help of its employees benefitting the students in the rural community or women self-help groups establishing themselves with the help and support of another EVP from the organisation. It could also be farmers gaining better produce by adopting scientific farming techniques from the knowledge they gained from classes provided by employee volunteers of an organisation's EVP program. The beauty of such program is that such program caters to the growth need of the employees. It helps employees to contribute something over and above their 'job requirement' and 'job description'. As Maslow's Need Hierarchy Theory points out, once lower order needs or deficiency needs are satisfied (in this case once the employees are reasonably satisfied with their job, their salary, their organisational environment) they start to look for ways to satisfy their higher order needs or growth needs.

CSR activities can thus satisfy the individual quest for growth by promoting active community involvement through EVPs. CSR activities transform work into something with a higher purpose, and this helps enhance the self-image of the employees who are involved in such activities. Young employees feel a sense of pride to be connected with the organisation which is socially responsible.

\section{Advantages to the Young Demography/Local Community}

It is a fact that the society's youngsters are in need of skill training. The current infrastructural and capital limitation of the government cannot address their skill training requirements. An effective public-private partnership can easily address this gap. With the mandatory CSR practices and promotion of active involvement of corporate sector in the skill training scenario, this 'skill gap' can be effectively and reasonably addressed. By promoting corporate involvement in the skill training sector, the government is increasing accessibility of skill training facilities and resource persons to the local demography. Such partnerships do not face the serious infrastructural or capital limitations of government-run Industrial Training Institutes (ITI) as the corporate sector comes equipped with its own set of independent establishments and employee volunteers. A well designed CSR framework and EVP 
that addresses any structural or resource gap and the ample supply of the CSR funds can come as a huge boon in the skill training arena especially for the youngsters in need of essential life skill training. Through the public-private partnership, internship opportunities, apprenticeship opportunities, on-the-job training, and field experience opportunities can also be provided. Such partnerships are mutually beneficial and come within the purview of CSR activities.

EVPs not only provide essential opportunities for employees to satisfy their growth needs, but also open up their specialised skill sets to the local community and society. A creative collaboration of the two parties, that is, the skilled employees from the organisation and the unskilled youngsters from the local communities, through the medium of Corporate Social Responsibility (CSR) where government plays the role of the mediator, can bear fruitful results for the future. CSR activities can provide opportunities for community service/ volunteering through Employee Volunteering Programs (EVPs). EVPs offer a learning environment that promotes skill and knowledge sharing between the employee and the local community and helps make an individual's work life more meaningful. EVPs typically help to have a positive impact on others' lives in addition to benefitting the worker (Grant, 2007; Pratt and Ashforth, 2003).

Through such EVPs, employees and the local community are mutually benefitted by knowledge sharing and skill up-gradation practices. There are instances where employees have benefited from the indigenous knowledge of the local community. There are also cases where more creative solutions have emerged for local issues through knowledge sharing between organisational representatives and locals. The corporate sector is benefitted by previously unavailable skilled workforce both locally and within the organisation. Such a CSR strategy will also ensure adequate CSR spends and help improve the social image of the corporate sector. The ripple effect is sustainable as locally up skilled workforce will ensure that the rest of their community gets the same advantage through them, in the future. A training initiative by HLL Lifecare indicates such a trend where local youth, trained by employee volunteers, later got imbibed as employees into the 
organisation and showed an active interest in engaging as employee volunteers for future community training initiatives intended at enhancing the skill level of the local community.

Career ready program conducted by Tata Steel is another such case in point where the organisation has been able to contribute actively to skill development and job placement for youths in Dharavi through its employee volunteers. DLF foundations' Nurturing Talent Programme is a scheme striving to promote the skill level of youth and advancing the cause of life skills education among students and aspiring professionals. IBM's Corporate Service Corps (CSC) is an EVP under its CSR initiative that actively acknowledges the benefit of involving employee with the local community for promoting social welfare. While society gets skilled professional help for problem-solving, employee volunteers get the opportunity to develop their leadership skills, interpersonal/intrapersonal skills, improve cultural awareness and gain awareness of new market through social exposure. IBM gets to promote its brand image while identifying new markets through its CSR activities. The program claims to have helped over 140,000 people through skill transfer and capacity building, since its inception in 2008(IBM, 2017). The corporate sector is thus beginning to realise the infinite potential of providing vocational training and skill development to the local community as CSR strategy through EVPs. This is evident in the current wave of schemes and scholarships offered by the sector to the local community.

\section{Conclusion}

CSR can become a self-sustaining activity with the active involvement of employees and the local community. It can be developed into a sustainable framework with the capability of achieving the crucial aim of Skilling India through active publicprivate partnerships. The government will benefit from corporate involvement - through human, social and capital investment. This will take a huge load off the government's shoulder and help it equip India's ever-growing young population with essential skills. The corporate sector benefits from the optimal utilisation of its CSR funds and strategy. It can also engage its employees by providing real-life training opportunities through EVPs, promote its brand 
image and identify new market by developing a skill training framework as its CSR strategy. Providing essential vocational training and skills development to the local community can ensure competent labour supply for the future. Employees also reportedly benefit by contributing productively through EVPs. Local community and society benefit from the opportunities provided by CSR activities for skill enhancement and skill up-gradation which provide them with a better quality of life. Thus skilling India's young population becomes an achievable reality through a sustainable CSR framework by promoting an active partnership between the government and the corporate sector.

\section{References}

Business4Better Thought Leadership. (2013). Seven practices of effective employee volunteering program. Retrieved from http:// www.pointsoflight.org/sites/default/files/resources/files/evp_fram ework_web_final.pdf

Bernhurt, S. (2012). Bansal, P. - Interview. Corporate social responsibility: Why good people behave badly in organizations. Ivey Business Journal, 18-20.

Bauman.C .W., \& Skitka, L. J. (2012). Corporate social responsibility as a source of employee satisfaction. Research in Organizational Behaviour. Retrieved from http://dx.doi.org/10.1016/j.riob.

Bosch. (2017, December 25). Retrieved from https://www.bosch.in/ ourcompany/our- responsibility/corporate-social-responsibility/

Brammer. S, Millington. A., \& Rayton, B. (2005). The contribution of corporate social responsibility to organizational commitment. School of Management - Working paper series: University of Bath

Colle, S., \& Gonella, C. (2003). Corporate social responsibility: The need for an integrated management framework. International Journal of Business Performance Management, 5(2/3), 199-212.

Wikipedia. (n.d.). Evolution of CSR in India. Retrieved April 15, 2015 from http://en.wikipedia.org/wiki/Evolution_of_corporate_social_responsibil ity_in_India

Gupta, M. D., Engelman, R., Levy, J., Luchsinger, G., Merrick, T., \& Rosen, J. E. (2014). State of World Population. Retrieved from https://www.unfpa.org/sites/default/files/pub-pdf/EN-SWOP14Report_FINAL-web.pdf 
Gond, P. J., El-Akremi, A., \& Igalens, J., Swaen, V. Corporate social responsibility influence on employees. No. 54-2010. ICCSR Research Paper Series. International Centre for CSR: Nottingham University Business School.

Gosh, S. (2017). Why corporate training in India is a $\$ 100$ bln domestic market in the making. Entrepreneur India. Retrieved from https://www.entrepreneur.com/article/277483

Joseph, M. P. (2014). Twelfth Five year plan: Expert committee on employment and skills development. Kerala: State Planning Board.

Joseph, P. K. (2015). Nurturing young talents. India CSR. Retrieved from www.indiacsr.in.

Krishnan, K. P., \& Nambiar, D. (2017). Skill India: Challenges, achievements and the way forward. Kurukshetra, 65(11). Publication Division, Ministry of I \& B.

Kumar, M. (2017). 3 Years of PM Modi: 'Sabka Saath, Sabka Vikas' Remains Just A Slogan. The Citizen. Retrieved from http://www.thecitizen.in/index.php/NewsDetail/ index/ 2/ 10713/ 3-Years-Of-PM-Modi-Sabka-Saath-Sabka-Vikas-Remains-Just-ASlogan

Lee, S. (2008). CSR in India. Retrieved from www.sbs.ox.ac.uk/ research/ corporate+social+responsibility

Mahesh, P. (2017). CSR \& business strategy. Retrieved from www.csrstrategies/intiatives-onceptpa

Mahapatra, S., \& Visalaksh, K. (2011). Emerging trends in corporate social responsibility: Perspectives and experiences from post-liberalized India. National Academy of Legal Studies and Research, University of Law, Hyderabad. Retrieved from http:/ / bit.ly/18dmQME

Ministry of Skill Development and Entrepreneurship. (2015). National Policy for Skill Development and Entrepreneurship. New Delhi.

Mitra, S. (2015). Why investing in children is good CSR. India CSR. Retrieved from www.indiacsr.in.

National Skill Development Mission. (2017). Retrieved from http:// www.skilldevelopment.gov.in/nationalskillmission.html

Pal, M. (2017). Skilling initiatives in rural India: An analysis. Kurukshetra. 65(11). Publication Division, Ministry of I \& B.

Pradhan Mantri Kaushal Vikas Yojana. (2017). Retrieved from http:/ / www.skilldevelopment.gov.in/pmkvy.html

Wikipedia. (n.d.) Pradhan Mantri Mudra Yojna. Retrieved September 15, 2017 from https:// en.wikipedia.org/ wiki/ Pradhan _Mantri _Mudra_Yojana 
Rupp, E. D., Williams, A. C., \& Aguilera, V. R. (2013). Increasing Corporate Social Responsibility through stakeholder value internalization (and the catalyzing effect of new governance): An application of organizational justice, self-determination, and social influence theories. Department of Psychology, University of Illinois, Urbana-Champaign.

Samhita. (2017). Skilling the unskilled: Why should the companies get involved? Part I. Retrieved from webhttp:// www.samhita.org/ skilling-the-unskilled-why-should-companies-get-involved-part-i/

Shivakumar, G. (2013). India is set to become the youngest country by 2020. The Hindu. Retrieved from http:// www.thehindu.com/ news/national/india-is-set-to-become-the-youngest-country-by2020/ article4624347.ece

Sing, S. (2017). Revamping the vocational education. Kurukshetra, 65(11). Publication Division, Ministry of I \& B.

Wikipedia. Skill. (n.d). Retrieved October 10, 2017, from https:// en.wikipedia.org/wiki/Skill.

Wikipedia. Skill India. (n.d.) Retrieved October 5, 2017 from https://en.wikipedia.org/wiki/Skill_India.

Some possible areas of Corporate Involvement. Retrieved October 5, 2017 from http://sbm.gov.in/cfd/CorpArea.aspx

Team Lease \& IIJT. (2009). India Labour Report 2009. Retrieved from http://www.teamlease.com/sites/default/files/resources/teamlease _labourreport2009.pdf

Tata Strategic Management Group. (2017). Skilling India: Opportunities and Imperatives for the Private Sector. Retrieved from http:// www.tsmg.com/download/article/Skilling\%20India\%20final.pdf

Tata Strive. (2017). Retrieved October 9, 2017 from http:// www.tatastrive.com/aboutStrive.html 